\title{
Dominant market position and ordoliberalism
}

\author{
Massimiliano Vatiero ${ }^{1}$
}

Received: 2 July 2014/Accepted: 29 August 2015/Published online: 5 September 2015

(C) Springer-Verlag Berlin Heidelberg 2015

\begin{abstract}
The ordoliberal distinction between performance competition and impediment competition may improve the understanding of the European distinction between a "dominant position" and an "abuse" of that position. Using a simple game-theory framework, I illustrate the dominant firm as a firm with, among other things, a dominant strategy in performance competition. If, due to the impediment condition, the dominant firm abandons its dominant strategy in the performance competition, then this firm is conducting abusively. In other words, the dominant firm should behave as-if it did not have economic power. It is the formulation of the ordoliberal as-if standard. As I show, such an ordoliberal standard leads to a wider concept of dominance that not only includes the economic domain but also considers the impact of private economic power on the political sphere.
\end{abstract}

Keywords Ordoliberalism · Market power - Dominant position

JEL Classification B13 $\cdot$ B2 $\cdot$ K21

\section{Introduction}

In the United Brands and Hoffmann-La Roche cases, the European Court of Justice (ECJ) offers definitions of a "dominant position" and of the "abuse" of such a position, which are still used today:

Massimiliano Vatiero

vatierom@usi.ch; massimiliano.vatiero@usi.ch

1 "Brenno Galli" Chair of Law and Economics, Institute of Law (IDUSI), Università della Svizzera italiana (USI), Lugano, Switzerland 
[A] position of economic strength enjoyed by an undertaking which enables it to prevent effective competition being maintained on the relevant market by giving it the power to behave to an appreciable extent independently of its competitors, customers and ultimately of its consumers (United Brands Company v. Commission, 1978, italics added).

In ECJ's decision, dominance is defined as the power to behave to an appreciable extent independently of the behaviours of others. However, European competition law does not impose sanctions on the dominant position, per se, but only its abuse. ${ }^{1}$ The Hoffmann-La Roche case delineated abusive conduct as behaviour

which, through recourse to methods different from those which condition normal competition in products or services on the basis of the transactions of commercial operators, has the effect of hindering the maintenance of the degree of competition still existing in the market or the growth of that competition (Hoffmann-La Roche v. Commission, 1979, italics added).

In the definition of the abuse of a dominant position, the ECJ seems to distinguish between two "kinds" of conduct: on the one hand, conduct based on "normal competition" on the merits (i.e. products and services); on the other hand, conduct with "methods different from normal competition" which can harm the competition of the market. ${ }^{2}$

The concept of dominance is not (solely) represented by the ability to raise prices, the ability which represents market power in economic textbooks (e.g. measured by Lerner index). Indeed, abusive behaviour consists of a larger inventory of practices than mere price-raising, such as predatory pricing, exclusive dealing, refusal to supply, tying, etc. ${ }^{3}$ This work starts from the fact that it is still difficult to translate into economic terms both the definition of dominant position and the distinction between the use and the abuse of dominant position (cf. on this difficulty see, for instance, Motta 2004: 34).

Hence, what does an "appreciable extent independently of" other agents mean in economic terms? Second, how should the distinction between "normal competition" and "methods different" from normal competition be translated into economic

\footnotetext{
${ }^{1}$ The ECJ affirms that:
}

a finding that an undertaking has a dominant position is not itself a recrimination but simply means that, irrespective of the reasons for which it has such a dominant position, the undertaking concerned has a special responsibility not to allow its conduct to impair genuine undistorted competition on the common market (NV Neverlandsche Banden-Industrie Michelin v. Commission, 1983).

2 The concept of abusive conduct is not limited to single-firm misconduct: under the idea of collective or joint dominance, several firms at once can abuse and share a dominant position (cf. Vatiero 2009a, b).

3 Art. 102 TFEU stipulates that

abuse may, in particular, consist in: (a) directly or indirectly imposing unfair purchase or selling prices or other unfair trading conditions; (b) limiting production, markets or technical development to the prejudice of consumers; (c) applying dissimilar conditions to equivalent transactions with other trading parties, thereby placing them at a competitive disadvantage; and, (d) making the conclusion of contracts subject to acceptance by the other parties of supplementary obligations which have no connection with such contracts. 
terms? To propose the answer to these questions, the work uses a simple gametheory framework to reappraise the ordoliberal thought which made a similar distinction between performance and impediment competition.

The choice to use the study of ordoliberalism ${ }^{4}$ to understand the meaning of dominance and its abuse is motivated by the fact that some commentators argue that European competition law, and in particular the norms on dominant position, derives from ordoliberal thought (Gerber 1998). ${ }^{5}$ Indeed, the concept of the abuse of a dominant position does not stem from US antitrust law, and is quite different from the US formulation of market power, which is based on the notions of "monopolization and attempted monopolization" as stated by $\$ 2$ of the Sherman Act. ${ }^{6}$ This difference is not only a matter of terminology. In US practice, the question of whether a behaviour is proper or not does not depend on the position that the firm occupies in the market; that is, anticompetitive conduct does not stem from the status of the firm (in theory, at least); in Europe, on the contrary, some modes of conduct that are legal when pursued by non-dominant firms are no longer legal when employed by dominant firms (see, among others, Vickers 2005). In particular, the ECJ states that the dominant position has some sort of special responsibility; i.e. the dominant firm has to abstain from "abusive" behaviours, even if these behaviours may be permissible for its competitors.

For ordoliberals, competition is the instrument used to dethrone economic power and the state has to take active measures to foster competition and to frustrate abusive conducts. Otherwise, power in the market will not only subvert the advantages offered by the market economy, but will also possibly undermine democracy itself, since strong economic power can be transformed into political power (see Sect. 5 below and also Vatiero 2010a). The ordoliberal perspective emphasizes the dangers economic power poses not only to efficiency and consumer welfare but also to democracy: "The goal of ordoliberal competition is the preservation of a free society" (Maier-Rigaud 2012: 136). Hence, to safeguard competition in particular and democracy in general, ordoliberals advanced the idea of the as-if competition. This paper will try to illustrate this notion in a (more) modern fashion and to offer a more comprehensive concept of dominance.

\footnotetext{
${ }^{4}$ For a review of the main ideas of ordoliberalism see, among others, Streit (1992), Gerber (1998), Maier-Rigaud (2012), Schnyder and Siems (2013) and Felice and Vatiero (2015).

5 David Gerber writes that:

The structure of the two main competition law provisions of the Rome Treaty (Articles 85 and 86) also closely tracked ordoliberal thought and bore little resemblance to anything to be found in other European competition laws at the time. While the prohibition of cartel agreements had analogues in US antitrust law, the concept of prohibiting abuse of a market-dominating positional was an important new development that was particularly closely associated with ordoliberal and German competition law thought and very different from the discourse of US law (Gerber 1998: 264).
}

However, some recent works show that there is null or little archival evidence in the preliminary works and drafts of the Rome treaty to prove the thesis of the ordoliberal origins of EU competition law (Akman 2009).

6 The restriction of market power is regulated in about half of the world's nations (cf. Hylton and Deng 2007). The two most famous laws on market power are Sect. 2 of the Sherman Act in the US and Article 102 TFEU. 
The paper is organized as follows: Sect. 2 introduces the notion of ordoliberal competition; in Sects. 3 and 4, I propose a game-theoretical illustration of dominant position and its abuse using the ordoliberal distinction between performance and impediment competition; Sect. 5 investigates the main differences between the as-if test and other current tests on dominance; Sect. 6 discusses some examples; and, finally, Sect. 7 outlines our findings and advances a research agenda.

\section{Ordoliberal competition(s)}

Some commentators affirm that German and European competition laws are in large part indigenous products (Gerber 1998). By around the end of the $18^{\text {th }}$ century in Vienna, a group of intellectuals (including, among others, Carl Menger and Eugen Bohm-Bawerk) began to investigate the law's crucial role in supporting competitive markets. During the Nazi regime, a group of lawyers and economists continued underground to develop such ideas on the strict connection between competition law and individual liberties. This group met at the Freiburg School of Law and Economics:

Close to the French and Swiss borders, home to liberal traditions, and far from the centres of German political and economic power, Freiburg provided a haven for a small group of intellectuals who rejected both Nazi totalitarianism and state socialism (Gerber 1998: 232).

In particular, one economist, Walter Eucken, and two lawyers, Franz Böhm and Hans Grossmann-Doerth, discovered in Freiburg that they each had a similar reading of the failings of the Weimar Republic, as well as similar views of what to do about it:

Each had concluded that the lack of an effective, dependable legal framework had led to the economic and political disintegration of Germany. Each believed that the core of the problem had been the inability of the legal system to prevent the creation and misuse of private economic power (Gerber 1998: 235).

For ordoliberals, ${ }^{7}$ the failure of the Weimar Republic derived mostly from the presence of a strong economic power that was not counterbalanced by a strong power of the state. A weak state was co-opted in the Weimar Republic by strong private economic interests and thus was not able to create and maintain the necessary conditions of competition. Having witnessed this use of private economic power to destroy political and economic institutions during the Weimar period, ordoliberals called for a strong state; that is, a strong guarantor of the free play of

\footnotetext{
7 The term ordoliberalism is applied to a somewhat broader stream of thought that featured the basic ideas of the Freiburg School but also included members who were not directly associated with Freiburg, such as William Röepke, Alfred Müller-Armack and Ludwig Erhard (who was the economics minister of the Federal Republic from 1949 through 1964 and its chancellor from 1964 to 1966).
} 
market forces. ${ }^{8}$ Accordingly, they believed that market processes fulfil positive functions only if the state establishes a strong institutional framework (the Ordo) within which they can take place.

Hence, ordoliberals rejected the idea of the minimal state; in their opinion, a laissez-faire economy would fail to ensure the proper working of markets due to an inherent tendency towards the cartelization and monopolization of markets (Eucken 1951). As noted by Eucken (1951: 83, italics added), property and freedom do not assure a competitive order:

[t]o an increasing extent, for example, "freedom of contract" is used to abolish competition by means of cartel agreements [...] Freedom of contract is often used to alter the form of the market and build up concentrations of economic power. As a result, it reduces economic freedoms of consumers. Moreover, such concentration of economic power can exercise strong lobbying and rent-seeking activities, threatening the normal functioning of democracy and, thus, the effective political liberties of citizens.

Ordoliberals called for the dispersion not only of political power, but also of economic power. It was not sufficient to protect the individual from the power of the government, because the government was not the only threat to individual freedom. Powerful economic institutions (e.g. cartels in the Weimar Republic) could also destroy or limit political freedoms.

For ordoliberals, competition law is "central to the economic constitution of society as a constraint on the exercise of both private and state power in the economic sphere" (Vickers 2005: F246). Competition law constrains economic power by punishing anticompetitive (i.e. abusive) conducts, and constrains political power as well by limiting discretionary public intervention in the economy. That is, competition law can safeguard citizens from (i) abuses of economic power and (ii) arbitrary uses of political power in the economy.

In this respect, competition law has to provide a standard of conduct for firms with economic power: economically powerful firms have to act as if they were subject to competition - that is, as if they did not have such economic power. This is the so-called as-if standard. ${ }^{9}$ It requires that firms refrain from conduct that would be unavailable to them if they had no market power.

This standard [the as-if standard] found support in a legal distinction that was developed in the 1920s and continues to be central to German competition law: [the] distinction between "performance competition" (Leistungswettbewerb) and "impediment competition" (Behinderungswettbewerb). The former included conduct that made a firm's products more attractive to consumers, typically by improving their characteristics or lowering their prices, while the latter referred to conduct designed to impede a rival's capacity to perform (Gerber 1998: 252-253).

\footnotetext{
${ }^{8}$ Some scholars have criticized this aspect of the ordoliberal programme as an inevitable threat to economic freedom. It is what Giuliano Amato calls the liberal dilemma - "the risk of 'too much' public power or, contrariwise, ‘too much' private power” (Amato 1997: 109).

9 The Ordoliberal Leonhard Miksch was the first to adopt the idea of as-if competition.
} 
In ordoliberal thought there is a noteworthy distinction between two kinds of competition: performance (or capacity) competition and impediment (or prevention) competition. The former refers to the conduct of firms in absolutely improving their own performance (better goods, lower prices, more service, innovation, etc.), whereas impediment competition refers to conduct aimed at deteriorating the performance of a firm's competitors.

Where market power could not be eliminated, the favoured competition law standard was that dominant firms should act as if constrained by competition. That would allow "performance competition" (Leistungswettbewerb) - to offer better deals to customer. But it would disallow "impediment competition" (Behinderungswettbewerb) - hindering rivals' ability to offer better deals to customers. In a competitive market there is naturally performance competition but no scope for impediment competition (Vickers 2005: F246F247).

For ordoliberals, the target of competition policy was to frustrate impediment competition and, thereby, foster performance competition.

The ECJ does not refer to this distinction (performance competition vs. impediment competition), but instead uses other terms (e.g. normal competition). However, this distinction, in accordance with Gerber (1998: 252), continues to be central to German competition law and, therefore, I believe it could also be useful for European competition law.

\section{Concepts}

The notion of dominance "does not preclude some competition", as stated in the Hoffman-La Roche decision:

[Dominant] position does not preclude some competition, which it does where there is a monopoly or quasi-monopoly, but enables the undertaking, which profits by it, if not to determine, at least to have an appreciable influence on the conditions under which that competition will develop, and in any case to act largely in disregard of it so long as such conduct does not operate to its detriment (Hoffmann-La Roche v. Commission, 1979, italics added).

The United Brands case has additionally made clear that a firm with $40 \%$ of the relevant market, while far from being a monopolist, might well be a dominant one. Hence, the idea of monopoly/monopsony does not coincide with the idea of dominance of the market; the latter is wider than the former and includes all cases in which a firm can operate to an "appreciable extent independently of" other competitors or parties, as stated by ECJ. ${ }^{10}$ Theoretically, the only case of perfect independence of other agents is the case of perfect competition because of pricetaking conditions: the firm takes the price as a given, independent of the choices and

\footnotetext{
${ }^{10}$ Moreover, not even the monopolist firm is independent of customers-least of all in the case of customers with a position of monopsony-because it still has to face market demand.
} 
behaviours of other players. However, this would imply (ironically!) that every player, among an unlimited number of players as assumed in perfect competition, has a dominant position without having relatively significant market power.

Hence, what does dominance means? It is hard to answer this question following the conventional distinction between perfect competition and monopoly structures. One possible explanation might be that the ECJ is in a muddle. Another might be that there are conceptions of "acting independently" that conventional neoclassical economics cannot precisely conceptualize.

Another answer, however, may derive from oligopoly theory. At first glance the oligopoly structure seems not to be consistent with the expression "to an appreciable extent independently of" others because in such a structure interdependences matter - the economic payoff of every firm depends to some degree on the choices of its competitors; however, in an oligopoly the choice of every firm is not always dependent on the choices of its competitors. In game-theory terminology, when the choice of a strategy is not influenced by other agents' choices (even if the outcome would be dependent on these choices), such a strategy is a dominant strategy. The definition of a dominant strategy in game theory-which implies the possibility of choosing without taking into account the other players' strategiesmay suggest a natural parallel with the occurrence of a firm with a dominant position, as originally proposed by Parcu (2006). This work will follow this suggestion.

Once introduced to the concept of dominance, we should analyse the concept of abusive conduct of a dominant firm. If it is difficult to define the meaning of dominant position in economic terms, then it is more difficult to illustrate in economic terms a particular type of conduct of a dominant firm: the abuse of its dominant position. The ECJ envisages two kinds of competition: "normal competition" and "methods different" which are able to harm competition in the market. Abusive conduct of a dominant firm relies on the latter kind of competition.

In the next section, I argue that performance competition is based on selfregarding choices (as a score-game), while impediment competition is based on relative-regarding choices (as a difference-game). ${ }^{11}$ In the latter type of conduct, the dominant agent may be more interested in the relatively negative effects of its conduct on other agents, rather than in its absolute positive payoff. The reference point of as-if competition is represented by choices which take into account only the score-game (that is, performance competition). In contrast, if choices depend on payoffs from the difference-game (that is, returns of impediment competition), then the firm bases its conduct on the relative consequences to others. For payoffs from impediment competition, the dominant firm may abandon its dominant strategy in the former (i.e. performance competition); this impairs performance competition.

\footnotetext{
11 Vatiero (2010b) refers to performance competition as Smithian competition, and to impediment competition as Veblenian competition.
} 
Fig. 1 Score-games

\begin{tabular}{l|c|c|} 
& \multicolumn{2}{|c}{$B$} \\
& $x$ & $y$ \\
\hline$x$ & $a, b$ & $c, d$ \\
\hline$y$ & $e, f$ & $g, h$ \\
\hline
\end{tabular}

\begin{tabular}{c|c|c|} 
B & \multicolumn{2}{|c}{$B$} \\
& $x$ & $y$ \\
\hline$x$ & 7,5 & 6,4 \\
\hline$y$ & 5,2 & 4,1 \\
\hline
\end{tabular}

Fig. 2 Difference-games

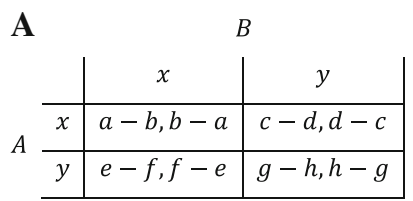

B
\begin{tabular}{c|c|c|}
\multicolumn{2}{c}{$B$} \\
$A$ & $x$ & $y$ \\
\hline$x$ & $2,-2$ & $2,-2$ \\
\hline$y$ & $3,-3$ & $3,-3$ \\
\hline
\end{tabular}

\section{Games of dominance and its abuse}

Shubik (1971) distinguished between the score-game and the difference-game. The score-game concerns "absolute" payoffs of the agents, while the difference-game is based on "relative" payoffs. These two types of games may be employed to propose the definitions of dominance and its abuse.

Consider the following games with two firms $(A ; B)$, where each firm has the set of strategies $(x ; y)$ :

In Fig. 1a, b, each payoff "scores" returns for the firm. In Fig. 2a, b, payoffs are derived as the difference of scores in the game in Fig. 1a, b, respectively:

More generally, if we denote the strategy space of the $i$ th agent by $S_{i}$, the payoff $P$ in the two-person score-games is given by $P_{i}\left(s_{i}, s_{j}\right)$ to the $i$ th player and by $P_{j}$ $\left(s_{i}, s_{j}\right)$ to the $j$ th player, while the payoff in the two-person difference-games is given by $P_{i}\left(s_{i}, s_{j}\right)-P_{j}\left(s_{i}, s_{j}\right)$ to the $i$ th player and the negative of this to the $j$ th player, with $i \neq j .{ }^{12}$

As noted by some scholars (Parcu 2006), the definition of a dominant strategy in game theory-which implies the possibility of choosing without taking into account other players' strategies - suggests a "natural" parallel with the occurrence of a firm with significant market power that we find in European antitrust law, i.e. the dominant position.

However, the dominant strategy can also characterize the strategic space $S$ of the non-dominant firm. The parallel between dominant position and dominant strategy, in fact, does not exclude the case in which the non-dominant firm also has a dominant strategy:

As a simple, extreme example, consider a firm with an inferior product that is evaluating whether to enter a market: if the firm realizes that entrance will cause only losses in all states of the world, it will have a dominant strategy, stay out, but certainly not a dominant position (Parcu 2006: 179, footnote 10).

\footnotetext{
12 Shubik also defined the status-game. Accordingly, a third type of game can be constructed as follows: The payoff in the status-game is equal to 1 if the firm is in the "status" of "winner" of the competition; namely, it has a positive payoff in the difference-game, while it is -1 if it loses and 0 if it draws.
} 


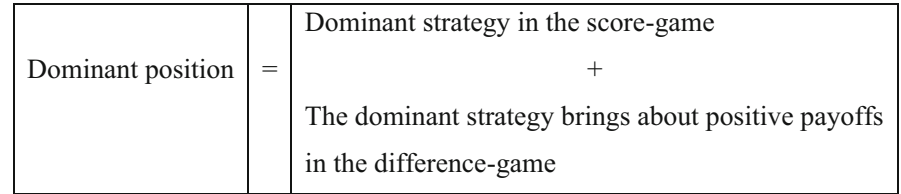

Fig. 3 The meaning of the dominant position in terms of game theory

For instance, in the score-game in Fig. 1b both firms have a dominant strategy, i.e. $x$. Hence, it is necessary to characterize the dominant position with a further condition that is able to distinguish the dominant firm from the non-dominant one(s).

In this respect, the ECJ affirms that the dominant firm has to "act largely in disregard of it so long as such conduct does not operate to its detriment." "Act largely in disregard" and "does not operate to its detriment" may stand for two meanings:

(i) the dominant strategy in the score-game determines only positive payoffs; and/or

(ii) such a dominant strategy in the difference-game determines only positive payoffs.

Both conditions represent a situation in which the dominant firm, behaving in accordance with its dominant strategy, produces benefits. In the former case, these benefits are intended in the absolute sense, and in the latter in the relative sense. However, while in the score-game positive payoffs from a dominant strategy may hold for both agents (such as in Fig. 1b), in the case of the difference-game this cannot occur. By definition, in the difference-game, only one of two agents can enjoy positive payoffs. The condition of positive payoffs in the difference-game is an asymmetric condition able to distinguish the market dominant firm from nondominant one. This is the case as illustrated in Figs. $1 \mathrm{~b}$ and $2 \mathrm{~b}$ : Firm $A$ is the dominant undertaking because it has a dominant strategy in the score-game (i.e. the strategy $x$ ) and the payoffs of its dominant strategy are positive in the differencegame. Summing up, the dominant strategy in the score-game with (also) positive payoffs in the difference-game illustrates an economic power and characterizes (only) the dominant player (Fig. 3).

However, this does not mean that in the difference-game the strategy $x$ (which is dominant in the score-game) is still the dominant strategy. For instance, in Fig. 2b, strategy $y$ is the dominant strategy in the difference-game for agent $A$. Therefore, the dominant firm could abandon its dominant strategy in the score-game (i.e. $x$ ) in order to choose another strategy consistent with the difference-game, namely strategy $y$. Hence, the dominant firm may switch from its dominant strategy in the score-game for incentives based on the difference-game. Such switching from one strategy to another allows us to illustrate the notion of abusive conduct: abusive conduct of a dominant firm is based on payoffs in the difference-game. In other 


\begin{tabular}{|l|l|l|}
\hline Dominant position & $=\begin{array}{l}\text { Dominant strategy in the score-game } \\
+ \\
\text { The dominant strategy brings about positive payoffs } \\
\text { in the difference-game }\end{array}$ \\
\hline Abusive conduct & $=$ & $\begin{array}{l}\text { The dominant firm abandons the dominant strategy } \\
\text { in the score-game due to payoffs in the difference-game }\end{array}$ \\
\hline
\end{tabular}

Fig. 4 The meaning of abusive conduct

words, the dominant position may be not aimed at obtaining the highest "absolute" payoff, but at getting the highest payoff relative to the competitors' payoffs.

I define a dominant firm as a firm which has a dominant strategy in the scoregame and positive payoffs in the difference-game. If payoffs of the difference-game are (marginally) relevant to the choices of the dominant firm (i.e. they are such that it abandons the dominant strategy from the score-game), then the firm is playing an abusive strategy (see Fig. 4). ${ }^{13}$

Using the terminology of ordoliberalism, this means that a dominant firm has a dominant strategy in performance competition and positive payoffs in impediment competition. If the payoffs of impediment competition are such that the dominant firm abandons its dominant strategy in the performance competition, then this firm is conducting an abusive strategy.

\section{An ordoliberal test?}

In the previous section, I have advanced the idea of a dominant undertaking giving up on a dominant strategy in the score-game due to payoffs in the difference-game. Does this idea provide us with a new test? The literature proposes several different tests to assess the conduct of a firm with market power (inter alia see Vickers 2005): the sacrifice test, the no economic sense test, and the equally efficient competitor test, just to cite a few. ${ }^{14}$ All of these tests are based on a criterion of efficiency (i.e.

\footnotetext{
13 The proposed illustration of (abuse of) dominant position is particularly useful in the case of competition which takes place in the market rather than for the market. I am in debt to an anonymous referee for this objection.

14 The sacrifice test refers to the anticompetitive strategy which consists of a willingness to sacrifice short-term revenues for the future benefits of high prices in a market from which rivals have been excluded and a monopoly has been created or the dominant position strengthened. The no economic sense test condemns exclusionary conduct when the conduct would make no economic sense but for its tendency to eliminate or lessen competition. Unlike the sacrifice standard, the recoupment is neither necessary nor sufficient for an anticompetitive effect in the no economic sense test: in the no economic sense test, the explanation of "irrational" conduct is the destruction or discipline of rivals (Werden 2006). Finally, Judge Posner proposed that a definition of monopolizing conduct would require "that the challenged practice is likely in the circumstances to exclude from the defendant's market an equally or more efficient competitor" (Posner 1991: 195). Under this test, which is called the equally efficient competitor test, the defendant's conduct would not be deemed unlawful monopolization unless the evidence proved that the conduct was likely under the circumstances to exclude from the market an equally efficient competitor.
} 
Fig. 5 Power and liberty

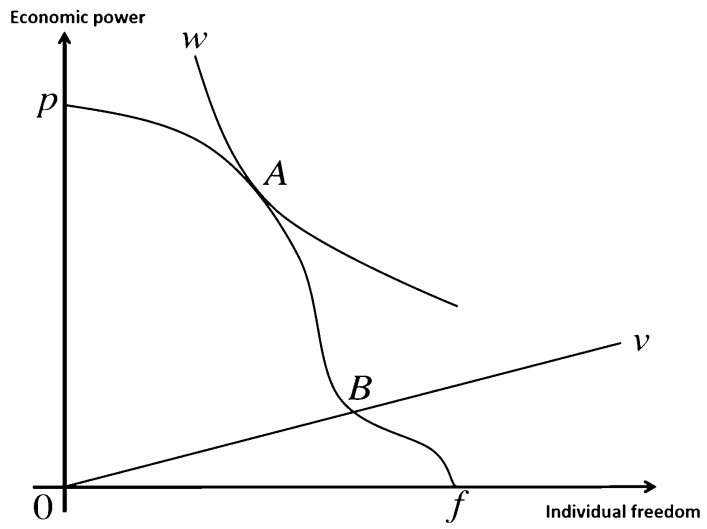

social welfare and/or consumer welfare). Although the ordoliberal as-if test also refers to a sacrifice in terms of opportunity costs for the dominant firm-the choice of a strategy in the score-game which is not dominant-the as-if test for ordoliberals should not be based on measures of efficiency or (utilitaristic) welfare. The as-if standard should instead be aimed at safeguarding individual freedoms.

The economic order is seen by ordoliberals as interdependent with the social political order, and the concept of freedom is applied much more broadly to the democratic order of society, rather than just to economic transactions and market participants. "The relations between economic and political power, usually to be found in mutual support of one another" (Eucken 1951: 272). Since private economic power has an inevitably undesirable impact on the political process and the stability of democracy, the enforcement of the as-if standard should/must lead to a free society (and not only to efficient outcomes). Rustow made this argument quite vividly:

we need to be prepared and would be prepared to defend that economic system that for non-economic reasons is a more desirable one, even if it were less productive than others. We would be prepared and should be prepared to accept economic sacrifices for that (quoted and translated in Maier-Rigaud 2012: 140).

For ordoliberals, freedom is the end of competition (and not a means) and represents a value in itself.

In this respect, a conflict between the goal of efficiency and the goal of freedom may arise. Let us indicate economic power by $P$ and individual liberty by $L$. Ordoliberals assume that an increase in economic power reduces individual liberty, that is, $\frac{\partial L}{\partial P}<0$. In Fig. $5{ }^{15}$ this negative ratio is represented by a negative sloped curve delimited by points $f$ and $p$. This curve identifies a sort of marginal rate of transformation between power and freedom. In the graph in Fig. 5, the level of power of a firm is on the $y$-axis while the level of individual freedom of citizens is

\footnotetext{
15 This illustration is derived from Vatiero (2010B).
} 
on the $x$-axis. The curve $w$ represents the marginal rate of technical substitution between power and liberty. It implies that point A is the Pareto optimum. Now, assume that society prefers a given power-liberty ratio, indicated with the line $v$. This means that for this societal preference the best point is B. For ordoliberals, the as-if test should assure a preferred power-liberty ratio (as point B), even if it does not assure the Pareto efficiency (as in point A).

Hence, for ordoliberals the concern is not with direct negative economic repercussions but rather with the threat that concentrated economic power poses to the competitive order (and therefore, indirectly, to economic efficiency) and to the socio-political order. In this respect, the as-if standard should be a way to protect competition, per se, because only competition can assure certain social benefits.

This view could extend to non-economic criteria (not included in the case of the sacrifice test, no economic sense test, equally efficient competitor test, etc.) the analysis of the conduct of the dominant market position and improve the current meaning of dominance in the market. For instance, Marsden et al. (2009) offer evidence of efforts by firms to influence the political environment (cf. also MaierRigaud 2012). Similarly, Michaelis (1994), McWilliams et al. (2002) and Oester (2007) argue that firms and industries may promote new regulations which will be to their comparative advantage; that is, regulatory barriers created by strategic lobbying of firms represent competitive weapons against other firms. ${ }^{16} \mathrm{~A}$ similar argument is also advanced for competition policy: "There is a spectre that haunts our antitrust institutions. Its threat is that, far from serving as the bulwark of competition, these institutions will become the most powerful instrument in the hands of those who wish to subvert it" (Baumol and Ordover 1985: 247). These kinds of conduct may harm competition and, therefore, according to ordoliberals, should be included in the set of anticompetitive and illegal behaviours. Interpreted in this fashion, by assessing not only the impact on the economic sphere but also the impact of private economic power on the political sphere, the ordoliberal as-if test is open to further scientific analysis.

\section{Discussing examples}

It is worth noting that my idea of abusive conduct is very similar to that of Elhauge (2003). He argues that a conduct is illegal if it should further monopoly power by impairing the efficiency of rivals even if the defendant did not successfully enhance its own efficiency. In contrast, if the defendant has improved its own efficiency in order to make a better or cheaper product, then its conduct is legal. However, as noted by the author, "conduct that is inefficient ex post to a firm's investment in creating, enhancing, or maintaining the sort of intellectual or physical property that is valuable enough to confer monopoly power is often efficient when viewed ex ante" (Elhauge 2003: 255). The distinction between an ex-ante and an ex-post view of efficiency represents the difference between the Elhauge and ordoliberal

\footnotetext{
16 A similar argument is that corporate actors (e.g. shareholders, managers, workers) may influence the polity along with their preferences. See, among others, Roe and Vatiero (2015).
} 
A

\begin{tabular}{|c|c|c|c|c|}
\hline \multirow{5}{*}{ dominant firm } & & $H$ & $M$ & $L$ \\
\hline & $H$ & 0 & 0 & 0 \\
\hline & $M$ & $k$ & $2 k$ & $k$ \\
\hline & & 2 & 3 & \\
\hline & $L$ & $k$ & $\frac{3 k}{2}$ & $2 k$ \\
\hline
\end{tabular}

B

\begin{tabular}{c|c|c|c|}
\multicolumn{5}{|c}{ others } \\
& $H$ & $M$ & $L$ \\
\hline$H$ & 0 & 0 & 0 \\
\hline$M$ & $k$ & $\frac{3 k}{2}$ & $2 k$ \\
\hline$L$ & $\frac{k}{2}$ & $\frac{2 k}{3}$ & $k$ \\
\hline
\end{tabular}

Fig. 6 Pricing of factor of production - payoffs of dominant firm, respectively, in the score-game and in the difference-game

arguments: while Elhauge justifies or condemns the conduct of firms with an ex-ante view of efficiency, the ordoliberal perspective refers mostly to the ex-post outcome and, above all, considers that efficiency is not the only component of the ex-post outcome.

Consider the following example. A firm acquires a factor of production at an $H$ (igh) price. Now, for an exogenous change (e.g. the price of oil), this firm can agree with the supplier in acquiring the same factor of production at either a $L$ (ow) price or a $M$ (edium) price. In the score-game, a low price determines an increase of profit for the dominant firm between $k$ and $2 k$ (with $k>0$ ) as in Fig. 6a, while the medium price causes an increase of profit between $\frac{k}{2}$ and $k$ as in Fig. 6a. The idea is that the reduction of the price of one of factors of production will increase profits. For the sake of simplicity, in Fig. 6a the strategy $H$ produces null payoffs (i.e. null increase of profit).

In the difference-game, let us assume that for this firm the payoffs are positive both in the case of strategy $L$ and in the case of strategy $M$, as in Fig. 6b. Hence, the firm has a dominant strategy $(L)$ and this strategy brings about positive payoffs in the difference-game; these are conditions for the definition of the dominant position. Perhaps, both strategies are justified along with Elhauge's argument because both strategies create efficiency improvements with respect to the ex-ante scenario, i.e. $H$ (igh) price.

Assume that the choice of the dominant firm may affect its competitors. Depending on the choice of the dominant firm, its competitors have be able to offer for the factor of production a price which is close to $L$ or to $M$-capacity constraints are assumed. Williamson (1968) in his investigation on the Pennington Case offers a good example in which the factor of production under investigation is the labour

A

\begin{tabular}{|c|c|c|c|c|}
\hline & & \\
\hline & & $H$ & $M$ & $L$ \\
\hline \multirow{4}{*}{ dominant firm } & null innovation & 0 & 0 & 0 \\
\hline & $S$ & $k$ & $2 k$ & $k$ \\
\hline & & & & \\
\hline & $W$ & $k$ & $\frac{3 k}{2}$ & $2 k$ \\
\hline
\end{tabular}

B

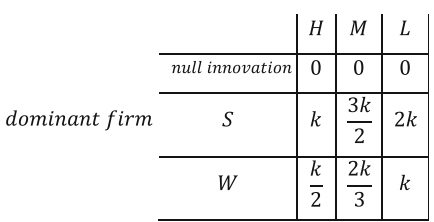

Fig. 7 Protection of innovation-payoffs of dominant firm, respectively, in the score-game and in the difference-game 
(and, in his view, the wage rates can be used to limit competition). Assume, as in Fig. $6 \mathrm{~b}$, that the strategy $M$, and not $L$, is the best strategy for the dominant firm in the difference-game. One reason is that the price $M$ can be relatively more costly to competitors than to the dominant firm-small and large firms usually experience a difference in average cost functions. Hence, the dominant firm may choose $M$ and abandon its dominant strategy $L$ to impair rivals and competition. In accordance with my (but not with Elhauge's) argument, this pricing conduct should be considered as abusive. The firm does not behave as-if it did not have an economic power (represented by asymmetries in the difference-game).

Consider a second example. A firm can produce an innovation which increases the social welfare (also including the consumer welfare). This firm can choose between two kinds of protection: $W$ (eak) or $S$ (trong) protection. For instance, the firm can invest a low level, say $W$, of resources in order to protect its innovation or a high level, say $S$, with $W<S$.

Assume payoffs as in Fig. 7a, b. The dominant firm could abandon its dominant strategy in the score-game (i.e. strategy $W$ ) for incentives of the difference-game. While both strategies are consistent with Elhauge's idea of legal conduct because both strategies produce efficiency improvements with respect to the scenario with no innovation, for my view, on the contrary, the strategy $S$ is abusive. One case of this strategy is in the Boosey and Hawkes (1987) case; the Commission found that Boosey and Hawkes had pursued unjustified litigation against its competitors for breach of copyright, which had the effect of imposing a heavy financial burden on these competitors. The abusive conduct in this case is represented by vexatious litigation of the dominant firm. The Commission concluded that a dominant firm may always take responsible steps to protect its commercial interests, but such measures must be fair and proportional to the threat. Hence, Boosey and Hawkes had chosen a level of protection, say $S$, that was heavier than the fair and proportional level, say $W$.

Finally, the ordoliberal as-if standard allows us to extend the analysis to the political sphere. For instance, the same firm could invest in order to call via politics for heavy and not soft regulations. Although an heavy regulation could represent a costly scenario for the dominant firm in the score-game, such regulation can create relatively higher difficulties and costs for actual and potential competitors. ${ }^{17}$ If so, the conduct of the dominant firm is abusive because it would not have called for heavy regulation if its economic power would not have determined asymmetric effects on other players in the market.

\section{Conclusions}

This paper tries to reinvigorate the fundamental ordoliberal question concerning the dangers of private economic power for society.

\footnotetext{
17 For instance, Marvel (1977) reports that the Lord Althorp's Factory Act of 1883 in Great Britain-an act which placed controls on the use of child labour in Britain's textile industry and banned the employment of children $<9$ years of age-was "designed to further the interests of a class of important textile manufacturers" (Marvel 1977: 380).
} 


\begin{tabular}{|l|l|}
\hline \multicolumn{1}{|c|}{ Definition of dominant firm } & \multicolumn{1}{c|}{ Definition of abusive behaviour } \\
\hline $\begin{array}{l}\text { Dominant strategy in the performance } \\
\text { competition (e.g., the strategy } x)\end{array}$ & $\begin{array}{l}\text { The dominant firm abandons the dominant } \\
\text { strategy in the performance competition } \\
\text { (e.g., the strategy } x \text { ) because of incentives or } \\
\text { payoffs from impediment competition }\end{array}$ \\
$\begin{array}{l}\text { The dominant strategy brings about positive } \\
\text { payoffs in the impediment competition }\end{array}$ & \\
\hline
\end{tabular}

Fig. 8 Re-defining dominance and its abuse

The ordoliberal distinction between performance and impediment competition may improve the understanding of abusive conduct by dominant firms. Indeed, this distinction may offer an illustration of the distinction between normal and nonnormal competition in ECJ's decisions: in short, our claim is that the performance competition of ordoliberals which is based on self-regarding choices, represents the "normal competition" of ECJ's decisions, while the impediment competition which is caused by relative-regarding concerns illustrates abusive conduct, i.e. "different methods from normal competition." As a result, the special responsibility assigned to the market dominant firm in accordance with Art. 102 TFEU can be illustrated as a mode for deterring strategies induced by impediment competition, and not coherent with performance competition.

In this paper, the abusive conduct of the dominant position is illustrated by a game with relative-regarded payoffs, which represents the idea of impediment competition of ordoliberals. The dominant firm may not choose its dominant strategy in the performance competition; namely, it may choose an abusive conduct based on incentives derived from the impediment competition (see Fig. 8). That is, impediment competition (or payoffs in the difference-game) may prompt a dominant firm to choose a strategy different from one it would choose in a performance competition (or score-game). When this occurs, in accordance with the views of ordoliberals, such conduct is abusive.

Moreover, the ordoliberal as-if standard is aimed not only at maintaining competition in the market but also at safeguarding freedoms of citizens which could be limited by the increase in economic power. However, one of the weaknesses of the as-if test is that it could be insufficient for ensuring a free society. The power in the market, and not only the abuse of that power, could lead to a restriction of freedoms. It is because the position of market power is an asymmetric position (by definition of power, cf. Vatiero 2009a) and, therefore, the choices of a dominant firm, even if in accordance with performance competition, could produce payoffs and consequences which are different/asymmetric between dominant and non-dominant firms in the market (e.g. negative payoffs in the difference-game). If so, normal competition and not only the abusive conduct of a dominant market position could reduce the number of competitors in a market and, as a by-product, affect freedoms. This is an issue which should be investigated in future research on the ordoliberal as-if standard.

Acknowledgments The author would like to thank Luca Fiorito, David Gerber, Nicola Giocoli, Michele Grillo, Antonio Nicita, Hans-Bernd Schäfer, two anonymous referees, and participants of the 
54th annual meeting of the Italian Economic Association (SIE) at the University of Bologna 2013 for helpful comments. Usual disclaimers apply.

\section{References}

Akman P (2009) Searching for the long-lost soul of Article 82EC. Oxf J Legal Stud 29(2):267-303

Amato G (1997) Antitrust and the bounds of power. Hart Publishing, Oxford

Baumol WJ, Ordover JA (1985) Use of antitrust to subvert competition. J Law Econ 28(2):247-265

Boosey v Hawkes [1987] OJ L286/36, [1988] 4 CMLR 67

Elhauge E (2003) Defining better monopolization standards. Stanf Law Rev 56:253-344

Eucken W (1951) The legal foundations of economics. Springer, London

Felice F, Vatiero M (2015) Ordo and European competition law. In: Fiorito L (ed) A research annual (research in the history of economic thought and methodology, vol 32). Emerald Group Publishing Limited, Bingley, pp 147-157

Gerber DJ (1998) Law and competition in twentieth century Europe. protecting prometheus. Oxford University Press, Oxford

Hylton KN, Deng F (2007) Antitrust around the world: an empirical analysis of the scope of competition law and their effects. Antitrust Law J 74(2):271-341

Maier-Rigaud F (2012) On the normative foundations of competition law-efficiency, political freedom and the freedom to compete. In: Zimmer D (ed) The goals of competition law. Edward Elgar, Northampton, pp 132-168

Marsden P, Kinsella S, McLeod R, Haines T, Lafitte J, Mitchener B, Harris C (2009) Lobbying competition law and policy. Concurrences 1(2009):11-33

Marvel H (1977) Factory regulation: a reinterpretation of early English experience. J Law Econ 20(2):379-402

McWilliams A, van Fleet DD, Cory KD (2002) Raising Rivals' costs through political strategy: an extension of resource-based theory. J Manage Stud 39(5):707-724

Michaelis P (1994) Regulate us, please-on strategic lobbying in cournot-nash oligopoly. J Inst Theor Econ 150(4):693-709

Motta M (2004) Competition policy. theory and practice. Cambridge University Press, Cambridge

Oester S (2007) The strategic use of regulatory investments by industry sub-groups. Econ Inq 20(4):604-618

Parcu PL (2006) European dominant position and American monopolization: a unifying approach from basic game theory. Banca Naz Lav Quart Rev 59(237):171-192

Posner R (1991) Antitrust law. The University of Chicago Press, Chicago

Roe MJ, Vatiero M (2015) Corporate governance and its political economy. In: Forthcoming on Oxford handbook on corporate governance. www.ssrn.com

Schnyder G, Siems MS (2013) The ordoliberal variety of neoliberalism. In: Konzelmann S, FovargueDavies M (eds) Banking systems in the crisis: the faces of liberal capitalism. Routledge, Abingdon, pp 250-268

Shubik M (1971) Games of status. Behav Sci 16:117-129

Streit ME (1992) Economic order, private law and public policy: the freiburg school of law and economics. J Inst Theor Econ 148:675-704

Vatiero M (2009a) Understanding power: a 'Law and Economics' approach. VDM-Verlag, Saarbrucken. www.ssrn.com

Vatiero M (2009b) An Institutionalist explanation of market dominances. World Compet 32:221-226

Vatiero M (2010a) Ordoliberal competition. Concorrenza e Mercato. Riv Annu Concorr 18:371-381. www.ssrn.com

Vatiero M (2010b) The Ordoliberal notion of market power: an institutionalist reassessment. Eur Compet 6:689-707. www.ssrn.com

Vickers J (2005) Abuse of market power. Econ J 115:F244-F261

Werden GJ (2006) Identifying exclusionary conduct under section 2: the no-economic sense test. Antitrust Law J 73(2):413-433

Williamson OE (1968) Wage rates as a barrier to entry: the Pennington case in perspective. Quart J Econ 85:85-116 